Impact Factor: 4.845(SJIF) Research Journal Of English (RJOE) Vol-5, Issue-1, 2020

www.rjoe.org.in An International Peer-Reviewed English Journal

ISSN: 2456-2696

Indexed in: International Citation Indexing (ICI), International Scientific Indexing

(ISI), Directory of Research Journal Indexing (DRJI) Google Scholar \& Cosmos.

\title{
THE IMPACTS OF INDIAN MYTHS IN BAAHUBALI (THE BEGINNING AND THE CONCLUSION)
}

\author{
K. Poompavai \\ 2B, $3^{\text {rd }}$ street Kosalai Nagar. \\ Gobichettipalayam, Erode(DT), Tamilnadu, India
}

\begin{abstract}
:
The Indian mythological storiesare one of the prides of our Indian literature and Baahubali takes our Indian cinema to international. Though Baahubali reaches international acclaim it has the influences of the Indian epics like the Mahabharata, the Ramayana and few avatar stories of Lord Vishnu. After watching the entire story of Baahubali people find several impacts of the Mahabharata among the characters and the story line. This paper deals with the impacts and influences of Indian myths in the films Baahubali the beginning and the conclusion.
\end{abstract}

Keywords: impact, Indian, movie, baahubali etc

\section{THE IMPACTS OF INDIAN MYTHS IN BAAHUBALI:}

In Baahubali Vikrama Deva and Bijjaladeva were brothers. After the death of their father, Mahismathi was ruled by the younger son Vikrama Deva. Bijjaladeva was a physically challenged person. He always misunderstood his father and his younger brother. He thought they refused his rights on the kingdom because of his physical condition. But the truth was he was mentally sick. After some period Vikrama Deva died in a war and his wife gave birth to Baahubali and dead. Shivagami, who was the wife of Bijjaladeva brought up her son Bhalla deva and Baahubali with the same kind. She announced that both of them had equal rights in this kingdom. And when they grew up people would like to have the younger son Baahubali to be their king. He was not only a good warrior but also a good soul by heart. Again, the jealous and the anger of Bijjaladeva rose in the case of his son. So, he plotted against Baahubali and he separated Baahubali and Shivagami. Though he knew that Baahubali was in love with Devasena, the princess of Kunthala, he told Shivagami that Bhalla was in love with Devasena. Without knowing the cunningness of her husband and 
Impact Factor: 4.845(SJIF) Research Journal Of English (RJOE) Vol-5, Issue-1, 2020

www.rioe.org.in An International Peer-Reviewed English Journal

ISSN: 2456-2696

Indexed in: International Citation Indexing (ICI), International Scientific Indexing (ISI), Directory of Research Journal Indexing (DRJI) Google Scholar \& Cosmos.

son,Shivagami misunderstood Baahubali and Devasena. Bhalla deva became king and Baahubali went out of the kingdom with his wife and lived with people.

Bijjaladeva and Bhalla deva created a fake story that Baahubali tried to kill Bhalla deva. On hearing this Shivagami ordered Katappa to kill Baahubali. Being a slave of Mahishmathi kingdom he follows the words and killed Baahubali. At the time Devasena gave birth to Mahendra Baahubali. When Shivagami came to know the truth, she announced that Mahendra Baahubali will be their new king. She took the child and went into a deep forest. For twenty-five years Devasena lived as a slave under Bhalla deva. Shivagami lost her life in a flood and the child was rescued by the people of a small village.

Mahendra didn't know about his past. He was named as Shivadu and was brought up in the village with much love. He fell in love with Avantika who was a revolutionist to rescue Devasena and Mahismathi kingdom from the hands of Bhalla deva. Instead of Avantika Mahendra went to rescue Devasena. In this mission, he killed Bhalla deva's son and came to know that he was Mahendra Baahubali. He also came to know that his father was killed by Katappa and Devasena was his Mother. He declared war on Mahismathi and Killed Bhalla deva. Finally, he became the king of Mahismathi. This is an outline of Baahubali the beginning and the Conclusion.

Amarendra Baahubali was the protagonist of this story. His character reflects the pandavas named Yudhishtira, Bhima, Arjuna, Nakula, and Sahadev. Baahubali was good in sword fighting, bow and arrow, and all the war principles and techniques. He learned all the Vedas and respect all the people. From his childhood, he shaped himself as a good human, a brave warrior and a loyal king. He was aone-man army.

Bijjaladeva had the similarity of Dhritarashtra. Dhritarashtra was the father of Kauravas, Bijjaladeva was the father Bhalla Deva. Both were the eldest sons of their family. Both were physically challenged. Dhritarashtra was blind. Bijjaladeva was unable to use his left hand. Both thought that their kingships were denied due to their physical illness. But the truth was both were selfish, dishonest and had a dysfunctional brain. 'As is the father so is the son' likewise both of their sons reflected the negative attitude.

Bhalla Deva's character had the influence of Duryodhana. He was the eldest son of Kauravas in the Mahabharata. Both Bhalla Deva and Duryodhana were antagonists of the plot. Both used Gadda as their weapon in war. Both lost their life because of their greed towards kingdom and woman. Though they were elders and good warriors they did not win people's hearts. So, they lost their opportunity to be a king in the people's heart. 
Impact Factor: 4.845(SJIF) Research Journal Of English (RJOE) Vol-5, Issue-1, 2020

www.rioe.org.in An International Peer-Reviewed English Journal

ISSN: 2456-2696

Indexed in: International Citation Indexing (ICI), International Scientific Indexing (ISI), Directory of Research Journal Indexing (DRJI) Google Scholar \& Cosmos.

The character Shivagami had been compared to the character of Sathyavati. Sathyavati was the wife of Santanu, the king of Hastinapur. Shivagami was the wife of Bijjaladeva. Both Shivagami and Sathyavati ruled the kingdom with the help of a warrior. In the case of Shivagami Katappa helped her. In the case of Sathyavati Bhishma helped her. Both were trust worthy and great warriors for their kingdom. Shivagami and Sathyavati played the role of Rajmata and ruled their kingdom without kings. Shivagami ordered Baahubali to capture Devasena, the princess of Kunthala to get married to her son Bhalla Deva. Sathyavati ordered Bhishma to kidnap the princess of Kashi to get married to her son Vichitravirya.

The next character was Devasena. She was compared with Draupadi. Draupadi rejected Karna in her swayamvar. Because Karna was the son of a charioteer. He belonged to Suta Caste. She married Arjuna and went to Hastinapur. There Pandavs told their mother that they brought a victory fruit to her. Kunti told them to share that fruit among themselves. Later she came to know that the fruit was Draupadi. So, she lived as a wife of pandavas. Devasena fell in love with Baahubali. When she came to Mahismati along with Baahubali, she came to know the truth. She shouted at Shivagami that she had the right to choose her life partner. Without her permission how Shivagami planned marriage for her along with her son Bhalla Deva? She had chosen Baahubali as her husband and she loved him too.

Both Devasena and Draupadi had a little controversy. In court (Swayamwar) Draupadi spoke out that she did not accept Karna as her husband. But in Hastinapur she did not argue with Kunti she followed the words of her Mother-in-law. But in the case of Devasena, she herself chose her husband and argue with her mother-in-law in the court.

Mahendra Baahubali had the similarities of Lord Krishna. Lord Krishna declared war on his uncle and won after he came to know the truth about his birth, he rescued his mother Devasena and declared war on his own kingdom to get back his crown. Here Devasena waited for her son nearly twenty-five years like herDevaki waited for her son Lord Krishna.

In Mahabharata, the Hastinapur Showed the royalty and the artistic quality of Pandavas. Here in Baahubali, the kingdom of Mahismathi reflected the same. Both kingdoms brought beauty to the setting of the plots. In Mahabharata Pandavas along with their wife Draupadi left Hastinapur for thirteen years. In Baahubali Amarendra Baahubali along with his wife Devasena left the kingdom of Mahismati after their marriage. In Baahubali The Beginning during the intermission Katappa took Mahendra Baahubali's feet and put it on his head. That particular posture resembled the Vamana avatar of Lord Vishnu.

These are the major impacts and influences between Indian myths and Baahubali the beginning and the conclusion. Not only the movie Baahubali has these impacts but also some 
Impact Factor: 4.845(SJIF) Research Journal Of English (RJOE) Vol-5, Issue-1, 2020

www.rioe.org.in An International Peer-Reviewed English Journal ISSN: 2456-2696

Indexed in: International Citation Indexing (ICI), International Scientific Indexing (ISI), Directory of Research Journal Indexing (DRJI) Google Scholar \& Cosmos.

other historical fictions and epic movies have the influence of Indian myths. The Indian myths are the pride of Indian Literature and Baahubali becomes the pride of Indian Cinema.

\section{References:}

- Baahubali The Beginning. Directed by S.S. Rajamouli, Arka Media, 2015.

- Baahubali The Conclusion. Directed by S.S. Rajamouli, Arka Media, 2017.

- Pai, Anant. 'Mahabharata'. Amar Chitra Katha. Vol 1,2 \& 3, 2010. 